\title{
OPTIMALISASI ASET DESA DI KABUPATEN KONAWE SELATAN
}

\author{
${ }^{1}$ Syamsul Alam, ${ }^{2}$ La Ode Mustafa \\ ${ }^{1}$ IImu Pemerintahan, Universitas Halu Oleo \\ ${ }^{2}$ IImu Politik, Universitas Halu Oleoi \\ e-mail correspondence: syamsulalam330@gmail.com \\ Kendari - Sulawesi Tenggara - Indonesia
}

\begin{abstract}
This study aims to analyze the optimization of village assets in South Konawe Regency. The research method used is a qualitative method approach where data collection is carried out in a natural setting with interview, observation and documentation techniques. The data analysis technique used is a qualitative analysis of the interactive model from Miles, Huberman \& Saldaña which includes data collection, data condensation, data presentation and conclusions/verification. The results of the study indicate that the optimization of village assets in Konawe Selatan Regency has not been carried out systematically as can be seen from the legal status determination of all village assets; not yet optimal use of all village assets to support governance, development, community development, and empowerment of village communities; and the utilization of village assets has not been carried out in the context of carrying out village government tasks.
\end{abstract}

Keywords: legal status; optimization; use; utilization; village assets

\begin{abstract}
Abstrak
Penelitian ini bertujuan untuk menganalisis optimalisasi aset desa di Kabupaten Konawe Selatan. Metode penelitian yang digunakan adalah pendekatan metode kualitatif di mana pengumpulan data dilakukan pada latar alamiah dengan teknik-teknik wawancara, pengamatan dan dokumentasi. Teknik analisis data yang digunakan adalah analisis kualitatif model interaktif dari Miles, Huberman \& Saldaña yang mencakup pengumpulan data, kondensasi data, penyajian data dan kesimpulan/verifikasi. Hasil penelitian menunjukkan bahwa optimalisasi aset desa di Kabupaten Konawe Selatan belum terlaksana secara sistematis sebagaimana yang terlihat dari belum dilakukannya penetapan status legal atas seluruh asset desa; belum optimalnya penggunaan seluruh aset desa untuk mendukung penyelenggaraan pemerintahan, pembangunan, pembinaan kemasyarakatan, dan pemberdayaan masyarakat desa; dan belum dilakukannya pemanfaatan aset desa dalam rangka penyelenggaraan tugas pemerintahan desa.
\end{abstract}

Kata Kunci: aset desa; optimalisasi; penggunaan; pemanfaatan; status legal 


\section{Journal Publicuho}

ISSN 2621-1351 (online), ISSN 2685-0729 (print)

Volume 5 Number 1 (February - April 2022) pp. $116-126$

Accredited SINTA SK.NOMOR 28/E/KPT/2019

Open Access at:http://ojs.uho.ac.id/index.php/PUBLICUHO/index

\section{PENDAHULUAN}

Desa, entitas inti dalam bangunan besar tatanan negara Republik Indonesia mempunyai kewenangan yang dilindungi oleh hukum. Dengan kewenangan legalnya tersebut, desa mengatur tata pemerintahan desa dan mengurus kepentingan masyarakat desa. Aktivitas pengaturan dan pengurusan dalam lingkup kewenangan desa menimbulkan aset desa. Aset desa mencakup barang milik desa yang bersifat strategis dan aset lainnya milik desa. Aset-aset ini dapat dibedakan menjadi aset ekonomi, aset lingkungan, aset kesehatan, aset pendidikan, aset sosial budaya dan warisan, dan aset perlindungan dan keamanan (Auditor-General, 2013).

Pemerintah desa berkewajiban secara normatif dan moral untuk melakukan optimalisasi aset desa. Optimalisasi aset adalah usaha memaksimalkan serta mengefektifkan penggunaan dan pemanfaatan asset (Hidayati, 2016). Optimalisasi diperlukan dalam seluruh rangkaian pengelolaan aset namun penekanan dalam optimalisasi aset desa perlu ditekankan pada penggunaan dan pemanfaatan asset (Widayanti, 2010). Tujuan optimalisasi aset adalah agar aset tersebut memberikan dukungan yang paling baik bagi penyelenggaraan pemerintahan desa dan pelayanan publik di desa. Optimalisasi aset dapat memberikan kontribusi yang penting bagi pemerintahan dan pengelolaan entitas publik serta proses perencanaan keuangan yang lebih luas. Optimalisasi aset desa menjadi basis dari kemandirian desa (IRE, 2016).

Banyak desa yang belum melakukan optimalisasi aset secara sistematis. IRE (2016) mengungkapkan bahwa di banyak desa konflik status aset desa meningkat. Selain itu, aset desa digunakan bukan untuk memberdayakan dan meningkatkan kualitas pelayanan publik yang berorientasi kemakmuran dan kesejahteraan masyarakat tetapi lebih untuk kepentingan mendorong pendapatan asli desa. Anwar (2016) menyatakan bahwa sebagian desa sudah melakukan optimalisasi aset tetapi belum sungguh-sungguh. Akibatnya, aset desa kurang jelas keberfungsiannya maupun dampaknya pada kesejahteraan masyarakat desa.

Optimalisasi aset desa secara konseptual merupakan fenomena administrasi publik. Administrasi publik adalah administrasi atau manajemen terhadap ranah pemerintahan dan aktivitas publik lainnya (Alam et al., 2016; Mustafa, 2021). Dalam proses optimalisasi tersebut, aset-aset diidentifikasi dan dikelompokkan berdasarkan potensinya atau berdasarkan sektorsektor unggulan menurut kriteria yang terukur dan transparan. Aset yang tidak dapat dioptimalkan dicari penyebabnya mengapa aset tersebut menjadi tidak fungsional (Siregar, 2004).

Optimalisasi aset desa dapat dijelaskan dengan Resources-Based Theory (RBT) atau seringkali disebut Resources-Based Views (RBV). RBT awalnya dikembangkan untuk sektor 
privat tetapi belakangan ini telah umum digunakan dalam organisasi sektor publik (Lee \& Whitford, 2013). RBT adalah kerangka kerja manajerial yang digunakan untuk menentukan sumber daya strategis potensial yang dapat memberikan keunggulan komparatif bagi organisasi. Penganjur RBT mengajukan postulat bahwa sumber daya yang dimiliki oleh organisasi adalah sumber utama dari kinerja dan keunggulan kompetitif (Juma, 2014; Jang, 2013). Dalam versi lain, postulat RBV mengatakan bahwa jenis sumber daya tertentu yang dimiliki dan dikendalikan oleh organisasi memiliki potensi dan harapan untuk menghasilkan keunggulan kompetitif yang pada akhirnya mengarah pada kinerja organisasi yang unggul (Ismail et al., 2012).

Optimalisasi aset merupakan bagian dari manajemen aset sehingga fenomena optimalisasi aset desa dapat pula dipahami dari sudut pandang teori manajemen. Manajemen adalah pencapaian tujuan organisasi secara efektif dan efisien melalui perencanaan, pengorganisasian, memimpin, dan mengendalikan sumber daya organisasi menurut (Daft, 2010). Pelaksanaan secara efisien dari fungsi-fungsi tersebut, menurut dan Robbins \& Coulter (2012), mengarah pada pencapaian tujuan-tujuan organisasi yang telah ditentukan sebelumnya. Tompkins (2005) mengatakan bahwa manajemen mengharmonisasikan seluruh aktivitas governing an organization lainnya dan karena itu memfasilitasi pencapaian tujuan-tujuan organisasional. Mullins (2005) mengatakan bahwa manajemen adalah batu loncatan bagi efektivitas organisasional.

Desa-desa di Kabupaten Konawe Selatan juga mempunyai aset desa sebagaimana disebutkan di atas. Aset-aset desa-desa dimaksud berupa barang bergerak dan barang tidak bergerak yang dibeli atau diperoleh atas beban APB Desa atau perolehan lainnya yang sah. Aset desa yang terlihat kasat mata antara lain bangunan gedung, kendaraan dinas dan perabot kantor desa, pasar desa, pasar hewan, tambatan perahu, lumbung pangan masyarakat, jalan usaha tani, drainase, lorong pemukiman warga, fasilitas air bersih, dan lainnya. Sebagian besar desa hanya memiliki aset lainnya milik desa, bukan aset desa yang bersifat strategis.

Belum ada analisis empiris sejauh mana dan bagaimana desa-desa di Kabupaten Konawe Selatan melakukan optimalisasi aset-asetnya, khususnya yang menyangkut optimalisasi status legal, penggunaan dan pemanfaatannya. Isu ini urgen karena dapat membantu mencerahkan pemerintah dan masyarakat desa di Kabupaten Konawe Selatan dalam rangka mendukung kebijakan dan program Desa Maju Konsel Hebat yang dicanangkan oleh pemerintah daerah sejak tahun 2016 dan merealisasikan visi pembangunan daerah "menuju Konawe Selatan sejahtera, unggul dan amanah berbasis perdesaan". 


\section{Journal Publicuho}

ISSN 2621-1351 (online), ISSN 2685-0729 (print)

Volume 5 Number 1 (February - April 2022) pp. 116-126

Accredited SINTA SK.NOMOR 28/E/KPT/2019

Open Access at:http://ojs.uho.ac.id/index.php/PUBLICUHO/index

\section{METODOLOGI}

Penelitian ini menggunakan kekayaan/khasanah penelitian kualitatif untuk menyajikan deskripsi yang komprehensif tentang optimalisasi aset desa. Hasil penelitian deskriptif ini berupa suatu gambaran rinci tentang jawaban atas pertanyaan penelitian yang telah diajukan sebelumnya. Sebagai penelitian kualitatif maka data mayor dalam penelitian ini adalah data kualitatif yakni data yang berbentuk wawancara terbuka, observasi, dokumen dan sejenisnya. Data kualitatif dalam penelitian ini dikumpulkan dari setting dunia nyata yang natural. Peneliti mengumpulkan data dan mencatat percakapan-percakapan dalam setting natural tersebut kemudian membuat interpretasi berdasarkan data tersebut dengan melibatkan beragam metode kualitatif yang sesuai sehingga dapat menemukan penjelasan dan pemahaman yang komprehensif tentang fenomena tersebut.

Mengacu kepada tradisi penelitian kualitatif, penelitian ini menetapkan secara purposif desa-desa lokasi studi lapang. Tipologi desa daratan dan desa pantai dianggap dapat menjadi pembeda utama aktivitas masyarakat dan pemerintahan desa yang berimplikasi pada optimalisasi aset desa. Berdasarkan pertimbangan tersebut ditetapkan 14 desa lokasi studi lapang, terdiri dari delapan desa dengan tipologi daratan dan enam desa dengan tipologi pantai. Kepala desa, sekretaris desa dan warga desa menjadi sumber data utama dalam penelitian ini, dilengkapi dengan hasil pengamatan dan dokumentasi. Teknik pengolahan data yang digunakan mengacu kepada model analisis interaktif dari Miles, Huberman \& Saldaña (2014) yang mencakup pengumpulan data, kondensasi data, penyajian data dan kesimpulan/verifikasi.

\section{HASIL DAN PEMBAHASAN}

Penyajian hasil dan pembahasan optimalisasi aset desa ini diorganisir menurut tiga tema yakni optimalisasi status legal, optimalisasi penggunaan dan optimalisasi pemanfaatan aset desa. Berikut adalah hasil-hasil empiris dan pembahasan terhadap ketiga tema dimaksud.

\section{Optimalisasi Status Legal Aset Desa}

Status legal aset desa mengacu kepada basis peraturan perundang-undangan dari pemilikan aset tersebut. Klaim terhadap pemilikan aset desa harus dapat dibuktikan landasan legalnya berupa peraturan perundang-undangan. Salah satu asas pengelolaan aset desa menurut ketentuan pasal 3 Peraturan Menteri Dalam Negeri Republik Indonesia Nomor 1 Tahun 2016 Tentang Pengelolaan Aset Desa adalah asas kepastian hukum. Hasil penelitian ini menunjukkan bahwa desa-desa di Kabupaten Konawe Selatan mempunyai aset berupa aset ekonomi, aset lingkungan, aset kesehatan, aset pendidikan, aset sosial budaya dan warisan, dan aset perlindungan dan keamanan.

Aset ekonomi antara lain badan usaha milik desa, kelompok tani, kios tani, lumbung pangan masyarakat, kandangnisasi, mesin parut kelapa, mesin pengolah tepung dan kopi, 
kolam ikan air tawar, jalan usaha tani, jalan produksi, hutan produktif, tanah kawasan hortikultura, dan jaringan listrik tenaga surya. Aset lingkungan antara lain tanah, kios tani, lumbung pangan masyarakat, pasar desa, tambatan perahu, jalan titian melingkar, jalan usaha tani, dan jalan produksi. Aset kesehatan mencakup pasokan air bersih, Polindes, Posyandu dan Poskesdes. Aset pendidikan hanya mencakup taman kanak-kanak dan bahan bacaan cetak. Aset sosial budaya dan warisan antara lain masjid, musholla, sanggar karang taruna, dan alat-alat olahraga. Aset perlindungan dan keamanan hanya mencakup Pos Kamling yang tidak dilengkapi dengan personil pertahanan sipil.

Aset lingkungan tersedia di semua desa, tetapi aset-aset lainnya relatif sedikit ketersediaannya. Hanya beberapa desa yang memiliki aset-aset lainnya (ekonomi, kesehatan, pendidikan, sosial budaya dan warisan, dan perlindungan dan keamanan). Tentu kondisi ini dapat mempengaruhi pilihan kebijakan pemerintah desa dalam usaha meningkatkan pembangunan dan pelayanan publik.

Sebagian besar dari aset lainnya milik desa yang disebutkan di atas diperoleh atas beban APB Desa. Namun demikian, beberapa desa melaporkan adanya aset yang diperoleh dari hibah dan sumbangan atau yang sejenis. Sebagai contoh, Desa Lambangi mempunyai aset bidang tanah masjid yang bersumber dari wakaf. Desa Langgapulu mempunyai tanah pasar desa yang bersumber dari hibah. Desa Puosu Jaya mempunyai aset bidang bangunan balai desa yang bersumber dari hibah. Desa Pombulaa Jaya mempunyai aset bidang tanah makam, tanah gedung TK, tanah lumbung pangan masyarakat dan kios tani, tanah masjid dan tanah musholla yang bersumber dari wakaf.

Ketentuan Pasal 6 ayat (2) Peraturan Menteri Dalam Negeri Republik Indonesia Nomor 1 Tahun 2016 Tentang Pengelolaan Aset Desa menyatakan bahwa aset desa berupa bangunan harus dilengkapi dengan bukti status kepemilikan. Hasil penelitian ini menunjukkan bahwa sebagian dari aset desa yang berupa bangunan desa mempunyai status legal yang kuat yakni dilengkapi dengan bukti status kepemilikan, tetapi sebagian lainnya belum mempunyai status legal yang kuat yakni belum dilengkapi dengan bukti status kepemilikan.

Aset desa berupa bangunan desa di desa-desa lokasi penelitian ini yang sudah mempunyai status legal yang kuat mencakup semua bangunan desa yang memang telah direncanakan oleh desa dalam RPJM Desa dan RKP Desa serta didanai oleh APB Desa. Sumber lisan mengatakan bahwa dalam pemerintah desa di Kabupaten Konawe Selatan mulai merencanakan pembangunan desa secara lebih otonom sejak tahun 2006 yakni sejak adanya kebijakan Alokasi Dana Desa (ADD) dari pemerintah pusat, kemudian diperkuat lagi dengan adanya Dana Desa yang mulai diimplementasikan sejak tahun anggaran 2015.

Seluruh bangunan desa di desa-desa lokasi penelitian ini yang diadakan atas beban APB Desa secara legal menjadi aset desa. Termasuk di dalamnya adalah kantor desa, balai desa, kantor badan permusyawaratan desa, gerbang batas desa atau gapura desa, masjid, 


\section{Journal Publicuho}

ISSN 2621-1351 (online), ISSN 2685-0729 (print)

Volume 5 Number 1 (February - April 2022) pp. 116-126

Accredited SINTA SK.NOMOR 28/E/KPT/2019

Open Access at:http://ojs.uho.ac.id/index.php/PUBLICUHO/index

DOI: http://dx.doi.org/10.35817/jpu.v5i1.23824

musholla dan bangunan lainnya milik desa. Namun demikian, berdasarkan hasil penelitian ini, di sejumlah desa sampel terdapat bangunan serupa yang belum memiliki status legal yang kuat. Di sejumlah desa terdapat bangunan serupa, yakni kantor dan masjid yang merupakan aset pemerintah kabupaten hanya saja aset tersebut berlokasi di desa. Sumber lisan mengatakan bahwa ada kantor desa yang dibangun atas biaya APBD Kabupaten Konawe Selatan dan sampai saat ini belum ada peraturan daerah yang menyatakan atau menegaskan tentang pengalihan aset tersebut ke Desa.

Ketidakjelasan status legal aset desa di desa-desa lokasi penelitian ini yang menonjol adalah pada aset tanah, antara lain tanah bangunan masjid, tanah jalan produksi, tanah jalan usahatani, tanah jalan lingkungan dan sejenisnya. Perihal tanah bangunan masjid, sumber lisan mengatakan bahwa sebagian desa sudah memiliki kejelasan status legal yakni sudah disertifikatkan atas nama desa yang bersangkutan. Namun, masih ada desa-desa yang memperoleh hibah tanah dari warga untuk pembangunan masjid desa namun tanah tersebut belum disertifikatkan atas nama desa. Mengacu ketentuan pasal 4 Peraturan Menteri Dalam Negeri Nomor 1 Tahun 2016 tentang Pengelolaan Aset Desa berarti bahwa tanah bangunan tersebut belum memiliki status legal yang kuat.

Perihal tanah yang diperuntukkan bagi jalan produksi, tanah jalan usahatani, tanah jalan lingkungan dan sejenisnya, sumber lisan mengatakan bahwa pada umumnya di Kabupaten Konawe Selatan belum memiliki status legal sebagai aset desa namun ada semacam pengakuan bahwa aset-aset tersebut adalah aset desa. Seluruh tanah yang diperuntukkan bagi jalan berskala lokal desa seperti jalan produksi, jalan usahatani, dan jalan lingkungan tetapi pemerintah kabupaten sudah pernah menyampaikan kepada desa agar dalam laporan aset desa mencantumkan aset-aset tersebut.

Data di atas menunjukkan bahwa di desa-desa lokasi penelitian di Kabupaten Konawe Selatan sudah ada sebagian aset desa yang mempunyai status legal yang kuat. Di sisi lain, sejumlah besar aset pemerintah kabupaten yang berskala lokal desa sudah diakui sebagai aset desa namun belum disertai dengan pemberian status legal yang kuat. Asetaset kabupaten yang berskala lokal desa tetapi didanai dari APBD Kabupaten seperti masjid dan kantor desa diakui sebagai aset desa namun belum disertai dengan pemberian status legal yang kuat. Aset-aset ini dalam kenyataannya sudah direhabilitasi, ditambah ataupun direnovasi dengan menggunakan dana APB Desa. Ada pula aset-aset berupa tanah peruntukan jalan yang berskala lokal desa dan sudah dibangun dengan dana APB Desa serta diakui sebagai aset desa tetapi belum disertifikatkan atas nama desa.

Fenomena status legal aset desa dan aset pemerintah kabupaten yang berskala lokal desa sebagaimana diuraikan di atas lebih tepat dijelaskan dengan menggunakan prinsip atau asas rekognisi dan subsidiaritas sebagaimana dikemukakan oleh Eko (2015). Asas 
rekognisi (pengakuan) terhadap aset-aset tersebut menunjukkan suatu penghormatan kesamaan status dan posisi desa sebagai kesatuan masyarakat hukum, dan juga menghargai keberagaman atau keunikan desa dalam rangka mencapai keadilan sosial. Konstitusi telah memberikan amanat kepada negara untuk mengakui dan menghormati desa atau yang disebut dengan nama lain sebagai kesatuan masyarakat hukum adat beserta hak-hak tradisionalnya. Asas rekognisi terhadap telah ditunjukkan dengan melakukan redistribusi ekonomi dalam bentuk alokasi dana dari APBN maupun APBD. Redistribusi uang negara kepada desa menurut Eko (2015) merupakan resolusi untuk menjawab ketidakailan sosial-ekonomi karena intervensi, eksploitasi dan marginalisasi yang dilakukan oleh negara.

Pengakuan atas aset desa sebagaimana ditemukan di desa-desa lokasi penelitian ini dapat dimaknai sebagai adanya pengakuan oleh pemerintah Kabupaten Konawe Selatan berkenaan dengan dua hal. Pertama, pengakuan bahwa urusan lokal atau kepentingan masyarakat setempat yang berskala lokal lebih baik ditangani oleh organisasi lokal, dalam hal ini desa, yang paling dekat dengan masyarakat. Akan lebih efisien jika ada lokalisasi penggunaan kewenangan dan pengambilan keputusan tentang kepentingan masyarakat setempat kepada desa. Kedua, pengakuan bahwa pemerintah Kabupaten wajib melakukan dukungan dan fasilitasi terhadap desa. Jadi, ada pengakuan/ kepercayaan dan ada fasilitasi kepada desa dalam rangka mengatur dan mengurus kepentingan masyarakat desa. Eko (2015) mengatakan bahwa tindakan pengakuan seperti ini sejalan dengan salah satu tujuan penting undang-undang desa yakni memperkuat desa sebagai subyek pembangunan, yang mampu dan mandiri mengembangkan prakarsa dan aset desa untuk kesejahteraan bersama.

\section{Optimalisasi Penggunaan Aset Desa}

Penggunaan aset desa yang dimaksudkan adalah kegiatan yang dilakukan oleh pengguna barang dalam menggunakan aset desa yang sesuai dengan tugas dan fungsi. Merujuk ketentuan Peraturan Menteri Dalam Negeri Nomor 1 Tahun 2016 Tentang Pengelolaan Aset Desa, empat kata kunci dalam mengoptimalkan penggunaan aset desa adalah: (1) menggunakan aset desa yang sesuai dengan tugas dan fungsi; (2) kepala desa menetapkan penggunaan aset desa; (3) sekretaris desa mengatur penggunaan aset desa; dan (4) petugas/pengurus aset desa yang berasal dari kepala urusan bertugas mengajukan permohonan penetapan penggunaan aset desa kepada kepala desa melalui sekretaris desa. Jika prosedur ini ditempuh dengan benar dan konsisten maka penggunaan aset desa dapat memberikan dukungan yang paling baik bagi penyelenggaraan pemerintahan desa.

Desa-desa di Kabupaten Konawe Selatan secara umum sudah menggunakan aset desa sesuai empat kata kunci tersebut di atas. Aset desa telah digunakan untuk dapat memberikan dukungan yang paling baik bagi penyelenggaraan pemerintahan desa, 


\section{Journal Publicuho}

ISSN 2621-1351 (online), ISSN 2685-0729 (print)

Volume 5 Number 1 (February - April 2022) pp. 116-126

Accredited SINTA SK.NOMOR 28/E/KPT/2019

Open Access at:http://ojs.uho.ac.id/index.php/PUBLICUHO/index

DOI: http://dx.doi.org/10.35817/jpu.v5il.23824

pelaksanaan pembangunan desa, pembinaan kemasyarakatan desa, dan pemberdayaan masyarakat desa. Aset desa yang bersifat strategis maupun aset lainnya milik desa semuanya digunakan untuk mendukung penyelenggaraan pemerintahan desa, pelaksanaan pembangunan desa, pembinaan kemasyarakatan desa, dan pemberdayaan masyarakat desa. Hanya saja, menurut sumber lisan tersebut, penggunaan sebagian aset desa tidak mengacu kepada penetapan penggunaan aset desa oleh Kepala Desa.

Di sebagian desa tidak ada penetapan petugas/pengurus aset desa yang berasal dari Kepala Urusan sehingga tidak ada pengajuan penetapan penggunaan aset desa secara berjenjang dari bawah melalui Sekretaris Desa sampai ke Kepala Desa. Akibatnya, ada sebagian aset desa yang lokasi penempatannya tidak didukung dengan atau tidak sesuai dengan penetapan Kepala Desa. Aset desa dalam bentuk persediaan barang tak habis pakai, seperti kursi, laptop, printer, in-focus, dan wireless, ataupun alat kantor dan rumah tangga seperti tong sampah, alat studio dan alat komunikasi seperti kamera digital dan amplifier, misalnya, dapat dipindahkan ke berbagai lokasi sehingga rawan terhadap risiko hilang dan rusak tanpa ada kejelasan siapa penanggung jawabnya yang dapat ditunjuk.

Selain itu, di beberapa desa, ada penggunaan aset desa untuk kepentingan yang bersifat sangat pribadi. Misalnya, laptop dan printer milik desa seringkali digunakan untuk keperluan tugas-tugas kuliah pejabat pemegangnya ataupun anggota kelvarganya. Beberapa jenis aset seperti kursi dan meja sering digunakan dalam acara-acara sosial budaya dan keagamaan seperti perkawinan, syukuran dan lainnya berdasarkan perintah lisan kepala desa. Meski demikian, beberapa sumber lisan menyatakan bahwa penggunaan aset desa untuk kepentingan di luar tugas dan fungsi pemerintah desa hanya dilakukan sepanjang tidak mengganggu atau menghalangi kelancaran tugas pemerintah desa di bidang penyelenggaraan pemerintahan desa, pelaksanaan pembangunan desa, pembinaan kemasyarakatan desa, dan pemberdayaan masyarakat desa.

Salah satu aset desa yang cukup strategis bagi peningkatan kesejahteraan masyarakat adalah Bumdes. Aset jenis ini tergolong aset ekonomi. Desa-desa sampel di Kecamatan Palangga umumnya mempunyai Bumdes yang dibentuk pada tahun 2015 lalu. Namun demikian, di sebagian desa, faktanya saat ini Bumdes tidak berjalan dengan baik, para peminjam dana tidak mengembalikan pinjamannya. Beberapa sumber lisan mengatakan bahwa saat ini ada pembicaraan informal di kalangan pemerintah desa untuk menggunakan aparat kepolisian dalam melakukan penagihan terhadap pinjaman macet tersebut namun sebagian warga tidak menyetujuinya.

Penyebab kemacetan Bumdes di desa-desa tersebut mencakup banyak faktor, namun faktor yang dominan menurut penilaian beberapa sumber lisan adalah karena 
pembentukan Bumdes dimotivasi oleh kepentingan politik pemilihan kepala daerah. Peneliti sendiri tidak dapat mengkonfirmasi kebenaran informasi tersebut dan cenderung berpendapat bahwa faktor penyebabnya adalah pembentukan Bumdes yang tidak diawali dengan studi awal yang cermat dan pengelolaannya yang tidak profesional. Sebagai contoh, semua desa tiba-tiba dalam waktu yang bersamaan membentuk Bumdes, dan setelah terbentuk, penyediaan pinjaman dana diakukan dengan jumlah yang sama untuk seluruh peminjam tanpa melihat apa kebutuhan usahanya.

\section{Optimalisasi Pemanfaatan Aset Desa}

Pemanfaatan aset desa yang dimaksudkan adalah pendayagunaan aset desa secara tidak langsung dipergunakan dalam rangka penyelenggaraan tugas pemerintahan desa dan tidak mengubah status kepemilikan. Bentuk pemanfaatan aset desa antara lain sewa, pinjam pakai, kerjasama pemanfaatan, dan bangun guna serah atau bangun serah guna. Pasal 11 ayat (1) Peraturan Menteri Dalam Negeri Nomor 1 Tahun 2016 Tentang Pengelolaan Aset Desa menegaskan bahwa pemanfaatan aset desa dapat dilaksanakan sepanjang tidak dipergunakan langsung untuk menunjang penyelenggaraan Pemerintahan Desa. Bentuk pemanfaatan aset desa dapat berupa sewa; pinjam pakai; kerjasama pemanfaatan; dan bangun guna serah atau bangun serah guna. Pemanfaatan aset desa sebagaimana dimaksud ditetapkan dalam Peraturan Desa.

Penelitian ini tidak menemukan adanya pemanfaatan aset desa dalam bentuk sewa, pinjam pakai, kerjasama pemanfaatan, dan bangun guna serah atau bangun serah guna sebagaimana yang disebutkan di atas. Aset desa, khususnya aset desa yang bersifat strategis, tidak ada yang layak dioptimalkan pemanfaatannya. Aset desa yang strategis berupa tanah hanyalah tanah peruntukan kantor desa dan jalan berskala lokal desa. Asetaset strategis tersebut tidak mungkin dioptimalkan melalui pemanfaatan dengan cara sewa, pinjam pakai, kerjasama pemanfaatan, dan bangun guna serah atau bangun serah guna sebagaimana dimaksudkan dalam peraturan perundang-undangan.

Selain itu, beberapa aset desa yang bersifat strategis yang ada di Kabupaten Konawe Selatan sebagaimana disebutkan di atas masih sulit untuk dioptimalkan pemanfaatannya karena hak penguasaannya belum memiliki basis legal yang kuat yakni belum ditetapkan dengan suatu peraturan perundang-undangan. Di sejumlah desa tanah peruntukan kantor dan tanah peruntukan jalan berskala lokal desa belum disertifikatkan atas nama pemerintah desa walaupun sudah ada pengakuan dari pemerintah Kabupaten Konawe Selatan. Demikian juga, di beberapa desa, bangunan kantor seperti balai desa, Poskesdes, dan Polindes belum disertai kepemilikan yang legal sedangkan sumber pengadaannya adalah anggaran pemerintah ataupun anggaran pemerintah daerah.

Hasil penelitian menunjukkan bahwa desa-desa di Kabupaten Konawe Selatan masih harus mengandalkan pengelolaan aset keuangan yakni Bumdes. Namun, pengelolaan aset 


\section{Journal Publicuho}

ISSN 2621-1351 (online), ISSN 2685-0729 (print)

Volume 5 Number 1 (February - April 2022) pp. 116-126

Accredited SINTA SK.NOMOR 28/E/KPT/2019

Open Access at:http://ojs.uho.ac.id/index.php/PUBLICUHO/index

kevangan ini harus benar-benar memperhatikan kaidah-kaidah pengelolaan yang baik. Pengalaman negatif beberapa desa di Kecamatan Palangga yang beramai-ramai membentuk Bumdes pada tahun 2015 perlu menjadi pelajaran bagi desa-desa yang lain. Bumdes dimaksud melayani kredit dengan plafon yang sama untuk semua orang. Hanya dalam waktu satu tahun, sejumlah Bumdes macet dan sampai sekarang pengembalian kredit belum tuntas. Pembentukan Bumdes baru tidak diawali dengan studi awal Participatory Rural Appraisal (PRA) kemudian dikelola secara profesional.

Bumdes yang sukses dan bertahan sampai sekarang adalah Bumdes Bhakti Mandiri di Desa Wawouru Kecamatan Palangga. Bumdes tersebut dibentuk pada tahun 2015. Di tahun 2016 modal keuangan Bumdes sebesar Rp 43.396.800, dan pada bulan Mei 2017 Kepala Desa melakukan penyerahan uang penyertaan modal usaha kepada Bumdes sebesar Rp 33.259.200. Sejak terbentuknya, Bumdes ini mempunyai dua unit usaha yakni permodalan dan saprodi. Pengelola Bumdes menyampaikan laporan pertanggungjawaban secara periodik. Sumber lisan mengatakan bahwa pengelolaan Bumdes Bhakti Mandiri dianggap sukses dan menurut penilaian dari institusi pengawasan keuangan daerah Bumdes ini dapat menjadi tempat studi banding bagi desa lainnya di Kabupaten Konawe Selatan yang hendak membentuk Bumdes.

\section{KESIMPULAN}

Desa-desa di Kabupaten Konawe Selatan memiliki aset desa baik jenis aset ekonomi, aset lingkungan, aset kesehatan, aset pendidikan, aset sosial budaya dan warisan, dan aset perlindungan dan keamanan. Namun, aset desa yang ada sangat minim dan relatif sulit dioptimalkan untuk kepentingan pembangunan desa secara umum kecuali untuk mendukung penyelenggaraan pelayanan publik di desa. Aset lainnya milik desa pada umumnya berfungsi operasional dan lebih bernilai sosial dibandingkan dengan nilai ekonomi. Pemerintah desa di Kabupaten Konawe Selatan belum melakukan optimalisasi aset desa secara sistematis. Sebagian aset desa sudah mempunyai status legal namun sebagian lainnya belum mempunyai status legal menurut mekanisme yang ditetapkan dalam peraturan perundang-undangan. Aset desa telah dioptimalkan penggunaannya tetapi belum dioptimalkan pemanfaatannya. Lagi pula, di sebagian desa tidak ada penetapan petugas/pengurus aset desa sedangkan di sebagian desa lainnya terdapat penggunaan aset desa yang tidak mengacu kepada penetapan penggunaan aset desa oleh Kepala Desa. 


\section{REFERENSI}

Alam, S., Rufini, L.O.M. \& Bake, J., 2016. Government Spending and People Welfare; in Southeast Sulawesi, Indonesia. The International Journal of Engineering and Science, Volume 5 Issue 11, pp. 78-85.

Anwar, M. Z., 2016. Aset Desa Sebagai Basis Desa Membangun. Diakses 22 Januari 2018 dari https://www.suarakebebasan.org/id/opini/item/

Auditor-General, 2013. Managing Public Assets. Discussion paper. Wellington : Office of the Auditor-General. Diakses 22 Januari 2018 dari https://www.oag.govt.nz/...publicassets/.../managing-public-...

Daft, R. L., 2010. Management. Mason, USA: South-Western, Cengage Learning.

Eko, S., 2015. Regulasi Baru, Desa Baru: Ide, Misi, dan Semangat UU Desa. Cetakan Pertama. Jakarta: Kementerian Desa, Pembangunan Daerah Tertinggal, Dan Transmigrasi Republik Indonesia.

Hidayati, S. N. R., 2016. Pengaruh Manajemen Aset Terhadap Optimalisasi Pemanfaatan Aset RSUD Pandan Arang Boyolali. Tesis. Surakarta: Program Magister Manajemen Sekolah Pascasarjana Universitas Muhammadiyah.

IRE (Institute for Research and Empowerment), 2016. Membangun Kemandirian Berbasis Aset Desa. Policy Brief 2016. Yogyakarta: IRE.

Ismail, A.I., Rose, R.C., Uli, J., and Abdullah, H., 2012. The Relationship Between Organisational Resources, Capabilities, Systems And Competitive Advantage. Asian Academy of Management Journal, Vol. 17, No. 1, pp. 151-173.

Jang, S. H., 2013. The Offensive Framework of Resource Based View (RBV): Inhibiting Others from Pursuing Their Own Values. Journal of Management and Strategy, Vol. 4, No. 1, pp. 62-69.

Juma, O. W. 2014. Organizational Resources, Corporate Governance Structures and Performance of Kenyan State Corporations. Doctoral disertation. Nairobi: School of Business, University of Nairobi.

Lee, S. Y., and Whitford, A.B., 2013. Assessing the Effects of Organizational Resources on Public Agency Performance: Evidence from the US Federal Government. Journal of Public Administration Research and Theory, Volume 23, Issue 3, pp. 687-712.

Miles, M.B, Huberman, A.M, \& Saldana, J., 2014. Qualitative Data Analysis, A Methods Sourcebook, Edition 3. USA: Sage Publications.

Mullins, L. J., 2005. Management and Organizational Behavior. London: FT Pitman.

Mustafa R., L. O., 2021. Birokrat Profesional di Organisasi Pemerintah Daerah: Profesional, Taktik dan Kendala. Kendari: Universitas Halu Oleo Press.

Robbins, S.P., and Coulter, M., 2012. Management. 11th Edition. New Jersey: Pearson Education, Inc., publishing.

Siregar, D.D., 2004. Manajemen Aset. Jakarta: PT. Gramedia Pustaka Utama.

Tomkins, J.R., 2005. Organization Theory and Public Management. Belmont, CA: Wadsworth.

Widayanti, E., 2010. Pengaruh Manajemen Aset Terhadap Optimalisasasi Pemanfataan Aset Tetap Pemerintah Daerah (Studi Kasus di Kabupaten Sragen). Tesis. Surakarta: Program Studi Magister Akuntansi Minat Utama Akuntansi Sektor Publik, Fakultas Ekonomi Universitas Sebelas Maret. 